\title{
Four new species of coccidia (Apicomplexa: Eimeriidae) from Owen Stanley skinks, Papuascincus stanleyanus (Sauria: Scincidae), from Papua New Guinea
}

\author{
Chris T. McAllister ${ }^{1}$, Donald W. Duszynski ${ }^{2}$ Robert N. Fisher $^{3}$ and Christopher C. Austin ${ }^{4}$ \\ ${ }^{1}$ Science and Mathematics Division, Eastern Oklahoma State College, Idabel, Oklahoma, USA; \\ ${ }^{2}$ Department of Biology, University of New Mexico, Albuquerque, New Mexico, USA; \\ ${ }^{3}$ U.S. Geological Survey, Western Ecological Research Center, San Diego Field Station, San Diego, California, USA; \\ ${ }^{4}$ Department of Biological Sciences and Museum of Natural Sciences, Louisiana State University, Baton Rouge, Louisiana, USA
}

\begin{abstract}
Between September and November 1991, 12 Owen Stanley skinks, Papuascincus stanleyanus (Booulenger) were collected from various localities on Papua New Guinea and examined for coccidians. Six (50\%) were found to harbour four eimerians that we describe here as new. Oocysts of Eimeria burseyi sp. n. were elongate to ellipsoidal with a bilayered wall and measured (length $\times$ width, $\mathrm{L} \times \mathrm{W}$ ) $36.0 \times 24.0 \mu \mathrm{m}$, with a L/W ratio of 1.5 . Both micropyle and oocyst residuum were absent, but a polar granule was present. Oocysts of Eimeria goldbergi sp. n. were ellipsoidal, with a bilayered wall, and measured $21.4 \times 16.1 \mu \mathrm{m}$; L/W ratio was 1.3. Both micropyle and oocyst residuum were absent, but a single or fragmented polar granule was present. Oocysts of Eimeria boulengeri $\mathrm{sp}$. $\mathrm{n}$. were spheroidal to slightly subspheroidal, with a thin, single-layered wall that readily collapses, and measured $16.0 \mu \mathrm{m}, \mathrm{L} / \mathrm{W}$ ratio was 1.0. Both micropyle and oocyst residuum were absent, but usually one (sometimes two) polar granule(s) were present. Oocysts of Eimeria niuginiensis sp. n. were oblong to tapered with a bilayered wall, and measured $20.0 \times 13.1 \mu \mathrm{m}$; $\mathrm{L} / \mathrm{W}$ ratio was 1.5 . A micropyle, oocyst residuum and polar granule were absent. To our knowledge, these represent the only coccidians ever described from P. stanleyanus.
\end{abstract}

Keywords: Coccidia, Eimeria, taxonomy, oocysts, taxonomy, hosts, Reptilia

Skinks of the genus Papuascincus Allison et Greer, 1986 are small diurnal and terrestrial lizards endemic to the island of New Guinea and restricted to the upper montane region $(>1000 \mathrm{~m}$ elevation and up to at least $3000 \mathrm{~m})$ in the central highlands and north coast ranges (Allison 1982, 1996, Zweifel 1980, Allison and Greer 1986). Species of Papuascincus are distinguished from other lygosomine skinks by pustulate structures on the surface of their egg shell, an apomorphy unique amongst skinks and possibly amongst squamates (Allison and Greer 1986).

The affinities of Papuascincus appear to lie with three other New Guinean genera, Lipinia Gray, 1845, Lobulia Greer, 1974 and Prasinohaema Greer, 1974, all members of a tribal level informal grouping among lygosomine skinks, the Sphenomorphus group sensu Greer (1979). Presently four species names are applied within $\mathrm{Pa}$ puascincus: P. morokanus (Parker), P. stanleyanus (Boulenger), P. buergersi (Vogt) and P. phaedoes (Vogt). The latter two taxa are known only from their holotypes, probably collected in the Sepik River Basin.
McAllister et al. (2013a) provided descriptions of two new isosporans from skinks of the genus Emoia Gray from Papua New Guinea (PNG) and the Fiji Islands. Their study represented the first report of coccidia from any reptile species from PNG. In addition, McAllister et al. (2013b-d, 2014) provided descriptions of new eimerians from Carlia Gray, Lipinia, Lamprolepis Fitzinger, and Sphenomorphus Fitzinger, skinks from the South Pacific, respectively. Although information is available on hemoparasites and helminths of Owen Stanley skinks (P. stanleyanus) from PNG (Austin and Perkins 2006, Bursey et al. 2008, 2010), nothing, to our knowledge, has been published on coccidia from this lizard. Herein, we provide descriptions of four new Eimeria spp. from P. stanleyanus from PNG.

\section{MATERIALS AND METHODS}

Between September and November 1991, 12 adult Papuascincus stanleyanus were collected by one of us (CCA) by hand or blowpipe from localities ranging from 1200-2000 $\mathrm{m}$ in Madang $(\mathrm{n}=11)$ and Morobe $(\mathrm{n}=1)$ provinces, $\mathrm{PNG}$, and examined for 
coccidians. Fresh faecal samples were placed in individual vials containing $2.5 \%(\mathrm{w} / \mathrm{v})$ aqueous potassium dichromate $\left(\mathrm{K}_{2} \mathrm{Cr}_{2} \mathrm{O}_{7}\right)$ and examined for coccidia by light microscopy after flotation in Sheather's sugar solution (specific gravity $=1.30$ ).

Measurements were taken on 25 sporulated oocysts using a calibrated ocular micrometer and reported in micrometers $(\mu \mathrm{m})$ with means followed by the ranges in parentheses; photographs were taken using Nomarski interference-contrast optics. Oocysts were $\sim 300$ days old when measured and photographed.

Descriptions of oocysts and sporocysts follow guidelines of Wilber et al. (1998) as follows: oocyst length (L) and width (W), their ranges and ratios $(\mathrm{L} / \mathrm{W})$, micropyle $(\mathrm{M})$, oocyst residuum $(\mathrm{OR})$, polar granule(s) (PG), sporocyst length (L) and width (W), their ranges and ratio (L/W), sporocyst (SP), Stieda body (SB), substieda body (SSB), parastieda body (PSB), sporocyst residuum (SR), sporozoite (SZ) anterior (ARB) and posterior (PRB) refractile bodies, and nucleus $(\mathrm{N})$.

Host vouchers were accessioned into the Texas Natural History Collection (TNHC), University of Texas, Austin, Texas, USA. Photosyntypes of sporulated oocysts were accessioned into the United States National Parasite Collection (USNPC), Beltsville, Maryland, USA. Lizard taxonomy follows the reptile database (Uetz and Hošek 2013). Unfortunately, no host tissues were made available for us to study.

\section{RESULTS}

\section{Eimeria burseyi sp. n.}

Figs. 1, 2, 9

Description of sporulated oocyst: Oocyst with 4 sporocysts; shape elongate-ellipsoidal; bilayered wall, colourless, $\sim 1.6$ thick, smooth outer layer, inner and outer layers of equal thickness; L $\times \mathrm{W}: 36.0 \times 24.0(35-38 \times$ 22-26); L/W: 1.5 (1.4-1.6); M, OR, PG: all absent.

Description of sporocyst and sporozoites: SP ovoidal, with a smooth unilayered wall, $\sim 0.4$ thick, composed of 2 valves joined by a longitudinal suture; $\mathrm{L} \times \mathrm{W}: 12.1 \times$ $10.6(12-13 \times 10-12)$; L/W: 1.1 (1.0-1.2); SB, SSB, PSB: all absent; SR: spheroidal, 6.0 (5-7), composed of moderately-sized globules in a compact mass or dispersed between SZ; SZ: sausage-shaped with spheroidal ARB and PRB; single N slightly posterior to midpoint of body.

Ty pe host: Papuascincus stanleyanus (Boulenger) (Sauria: Scincidae). Collected 8 September 1991.

Type locality: Kaironk Village, $10 \mathrm{~km} \mathrm{NW}$ of Simbai, Madang Province, Papua New Guinea (514'15"S; $\left.144^{\circ} 28^{\prime} 50^{\prime \prime} \mathrm{E}\right)$

Other host species: None.

Prevalence: In one of $12(8 \%)$ of the type host.

Site of infection: Unknown, oocysts recovered from faeces.

Materials deposited: Symbiotype host in the TNHC as No. 51767. Photosyntype of sporulated oocyst deposited in the USNPC as No. 106457.

Etymology: The specific epithet is given in honour of Dr. Charles R. Bursey, Professor of Biology, Pennsylvania State University-Shenango Campus, Sharon, Pennsylvania, USA, in recognition of his contributions to our knowledge of the helminth parasites of $P$. stanleyanus.
Remarks. We have placed this new coccidium tentatively in the genus Eimeria Schneider, 1875, because the sporulated oocysts are tetrasporocystic. However, we are fully aware that some tetrasporocystic eimeriid-like coccidians have been separated from Eimeria (such as Choleoeimeria Paperna et Landsberg, 1989, Acroeimeria Paperna et Landsberg, 1989), because they exhibit a suite of very specific characteristics in both endogenous and exogenous stages that differentiate them from members of Eimeria (e.g. sporulated oocysts significantly longer than wide, endogenous sporulation, sporocysts with wall sutures, endogenous development in gall bladder and bile duct epithelium, others; see Paperna and Landsberg 1989, Modrý and Jirků 2006, Sloboda and Modrý 2006). Although E. burseyi sporocysts seem to have a distinct suture, we have no other empirical evidence that our oocysts were shed completely sporulated or that the endogenous stages that produced these oocysts were located in the gall bladder/bile duct epithelium. Thus, we take the conservative path not to place this species into the genus Choleoeimeria until endogenous and/or molecular evidence is available to do so (or not).

In comparing sporulated oocysts (the only stage available to us) to those most similar in structure, those of E. burseyi are most similar to the oocysts of Choleoeimeria saqanqouri Abdel-Baki, El-Fayomi, Sakran et Abdel-Haleem, 2008, from the sandfish skink, Scincus scincus Linnaeus from Egypt (Abdel-Baki et al. 2008). However, the bilayered oocyst wall of $C$. saqanquori measures $1.0 \mu \mathrm{m}$, whereas that of $E$. burseyi is thicker $(1.6 \mu \mathrm{m})$ and the sporocyst width (and range) is larger in E. burseyi (10.6 [10-12] vs 8.9 [7.5-10] $\mu \mathrm{m})$. We make this comparison because E. burseyi might be found later to have molecular or endogenous characters to allow its placement in the genus Choleoeimeria (see Discussion).

\section{Eimeria goldbergi sp. n.}

Figs. 3, 4, 10

Description of sporulated oocyst: Oocyst with 4 sporocysts; shape ellipsoidal; bilayered wall, colourless, $\sim 1.4$ thick, smooth outer layer $\sim 0.8-1.0$, inner layer $\sim 0.4-0.6$; $\mathrm{L} \times \mathrm{W}: 21.4 \times 16.1(20-23 \times 15-19)$; L/W: $1.3(1.2-1.5)$; M, OR: both absent; PG: single or often fragmented.

Description of sporocyst and sporozoites: SP ovoidal, with a smooth unilayered wall, $\sim 0.4$ thick, composed of 2 valves joined by a longitudinal suture; $\mathrm{L} \times \mathrm{W}: 9.4$ $\times 6.9(8-10 \times 6-8) ; \mathrm{L} / \mathrm{W}: 1.4(1.2-1.6) ; \mathrm{SB}, \mathrm{SSB}, \mathrm{PSB}$ : all absent; SR: spheroidal, 3.0 (2.6-3.2), composed of moderately sized globules dispersed between SZ; SZ: sausage-shaped, 2.5 wide (2-3), with spheroidal ARB 1.9 (1.6-2.4) and spheroidal PRB 2.5 (2.2-2.6); single N slightly posterior to midpoint of body.

Type host: Papuascincus stanleyanus (Boulenger) (Sauria: Scincidae). Collected 8 September 1991.

Type locality: Kaironk Village, 10 km NW Simbai, Madang Province, Papua New Guinea (5¹4'15"S; 144² $\left.28^{\prime} 50^{\prime \prime} \mathrm{E}\right)$. 

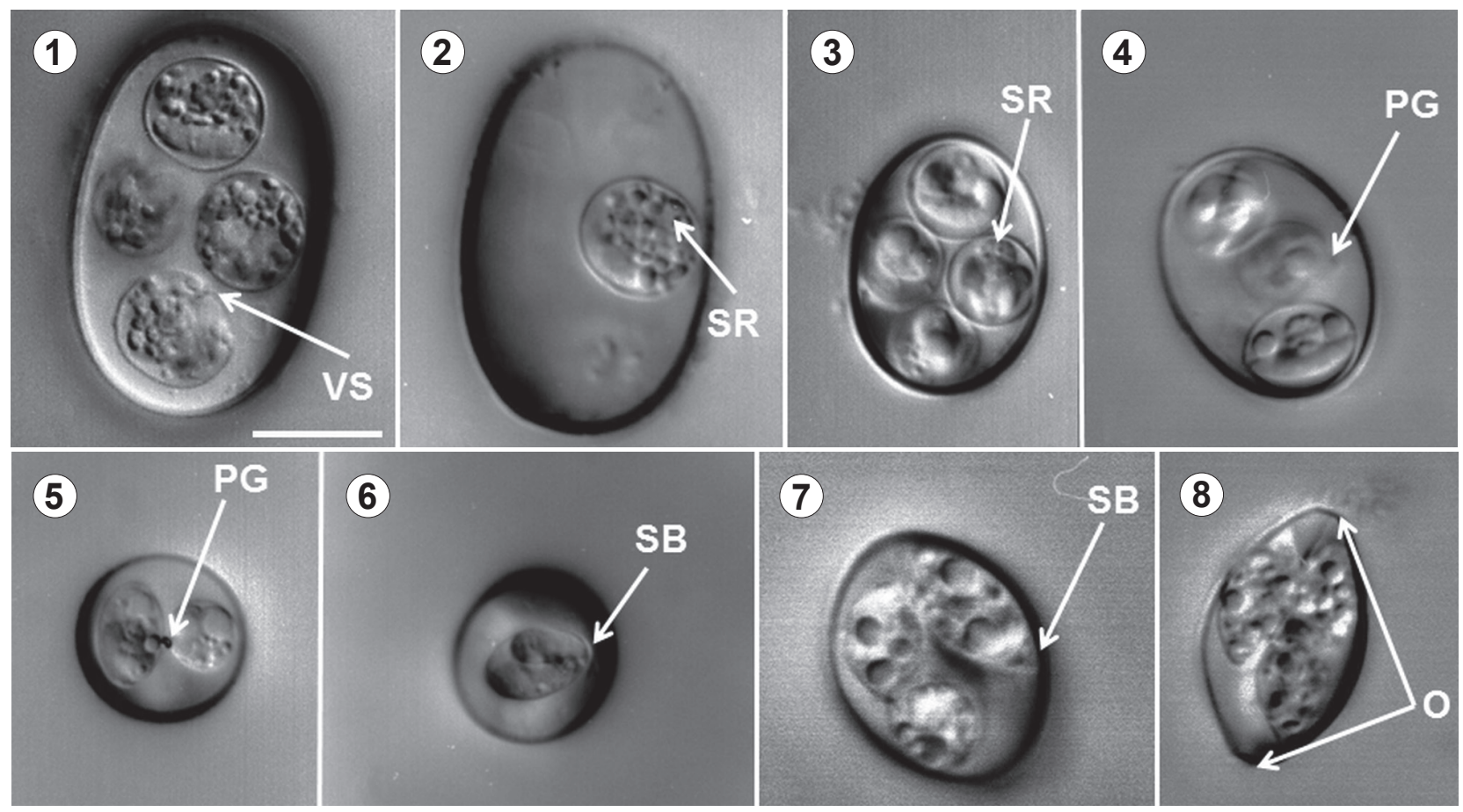

Figs. 1-8. Oocysts of new species of Eimeria from Papuascincus stanleyanus, Nomarski interference-contrast photomicrographs. Figs. 1, 2. Eimeria burseyi sp. n. Figs. 3, 4. Eimeria goldbergi sp. n. Figs. 5, 6. Eimeria boulengeri sp. n. Figs. 7, 8. Eimeria niuginiensis sp. n. Abbreviations: O - oocyst; PG - polar granule; SB - Stieda body; SR - sporocyst residuum; VS - valve suture. Scale bar $=10 \mu \mathrm{m}$ for all figures.

Other host species: None.

Prevalence: In three of $12(25 \%)$ of the type host.

Site of infection: Unknown, oocysts recovered from faeces.

Materials deposited: Symbiotype host in the TNHC as No. 51772. Photosyntype of sporulated oocyst deposited in the USNPC as No. 106458.

Etymology: The specific epithet is given in honour of Stephen R. Goldberg, Professor of Biology, Whittier College, Whittier, California, USA, in recognition of his contributions to our knowledge of the helminth parasites of $P$. stanleyanus.

Remarks. Similar to the reasoning and argument presented above for E. burseyi, we also have placed this new coccidium, tentatively, into the genus Eimeria because the sporulated oocysts are tetrasporocystic. Sporulated oocysts of E. goldbergi are most similar in size to two other Eimeria-like coccidians from skinks with intracytoplasmic development, but considered by Modrý and Jirků (2006) to be insertae sedis as follows: Eimeria ablephari Cannon, 1967 from the snake-eyed skink, Cryptoblepharus boutonii (Des Jardin) from Australia has oocysts that measure $23.1 \times 17.7 \mu \mathrm{m}(\mathrm{L} / \mathrm{W}=1.3)$ and SP that measure $8.9 \times 6.6 \mu \mathrm{m}(\mathrm{L} / \mathrm{W}=1.3)($ Cannon 1967) and Eimeria maboia Carini, 1938, from the Paraguay mabuya, Aspronema dorsivittata (Cope) and the greater Martinique skink, Mabuya mabouia (Bonnaterre) from Brazil (Carini 1938) that possesses oocysts that measure $20 \times 17 \mu \mathrm{m}(\mathrm{L} / \mathrm{W}=1.2)$ and SP that measure $9 \times$
$7.5(\mathrm{~L} / \mathrm{W}=1.2)$. However, E. goldbergi possesses a PG, while E. ablephari and E. maboia do not.

\section{Eimeria boulengeri sp. n.}

Figs. 5, 6, 11

Description of sporulated oocyst: Oocyst with 4 sporocysts; oocyst shape spheroidal to slightly subspheroidal; thin, colourless, unilayered wall, $\sim 0.8$ thick (readily collapses); L $\times \mathrm{W}: 16.0$ (14-18); L/W: 1.0 (1.0-1.1); M, OR: both absent; PG: usually 1 , sometimes $2, \sim 2.0$ wide.

Description of sporocyst and sporozoites: SP ovoidal, with a smooth, thin, colourless unilayered wall; $\mathrm{L} \times$ $\mathrm{W}: 9.8 \times 6.5(9-11 \times 6-10)$; L/W: $1.5(1.1-1.8)$; SB: very small; SSB, PSB: both absent; SR: spheroidal, 2.8 (2-3), composed of moderately-sized globules dispersed between SZ; SZ: sausage-shaped with spheroidal ARB 1.9 (1-3) and ovoidal PRB $3.6 \times 2.7(2-6 \times 2-3)$; single $\mathrm{N}$ slightly posterior to midpoint of body.

Type host: Papuascincus stanleyanus (Boulenger) (Sauria: Scincidae). Collected 8 September 1991.

Type locality: Kaironk Village, 10 km NW Simbai, Madang Province, Papua New Guinea ( $\left.5^{\circ} 14^{\prime} 15^{\prime \prime S} ; 144^{\circ} 28^{\prime} 50^{\prime \prime E}\right)$.

Other host species: None.

Prevalence: In one of $12(8 \%)$ of the type host.

Site of infection: Unknown, oocysts recovered from faeces.

Materials deposited: Symbiotype host in the TNHC as No. 51776. Photosyntype of sporulated oocyst deposited in the USNPC as No. 106459. 

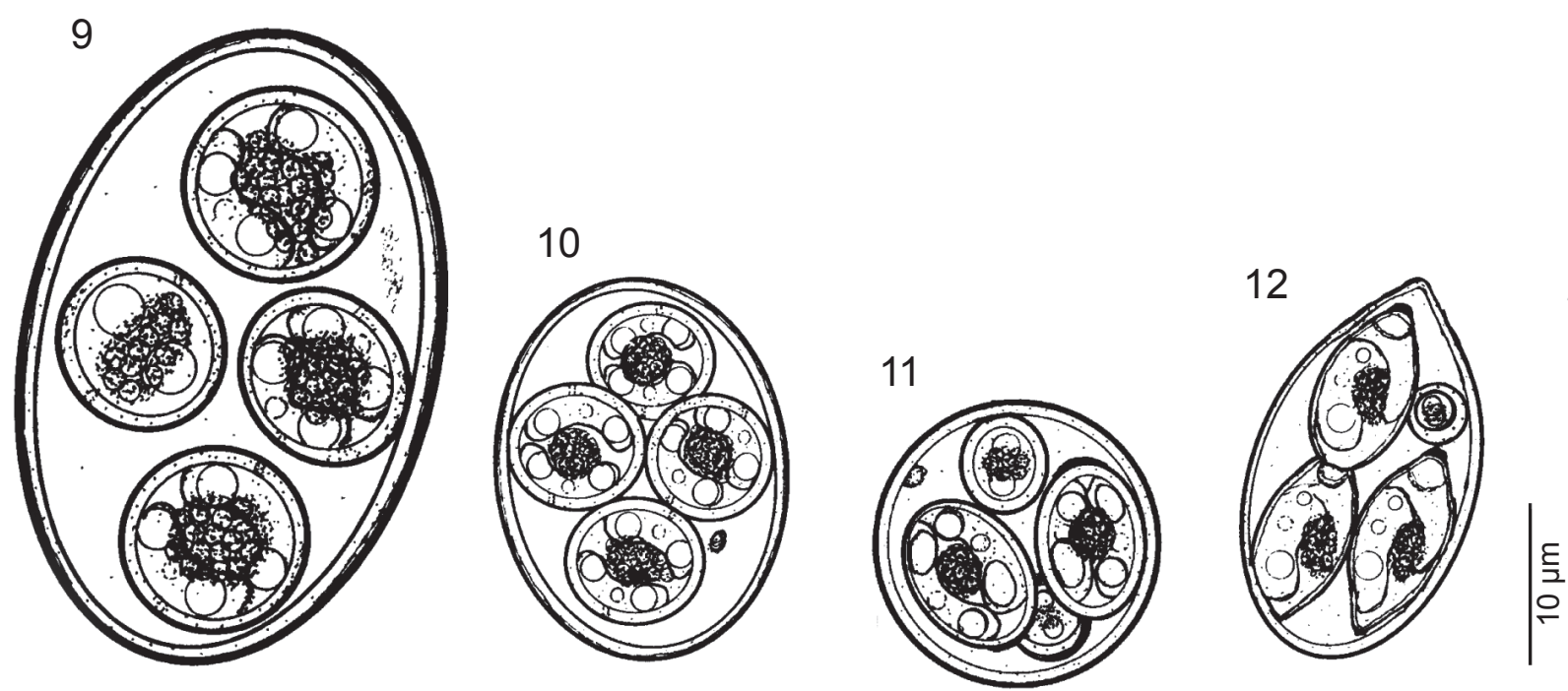

Figs. 9-12. Oocysts of new species of eimeria from Papuascincus stanleyanus; composite line drawings of. Fig. 9. Eimeria burseyi sp. n. Fig. 10. Eimeria goldbergi sp. n. Fig. 11. Eimeria boulengeri sp. n. Fig. 12. Eimeria niuginiensis sp. n.

Etymology: The specific epithet is given in honour of Belgian taxonomist Dr. George Albert Boulenger (1858-1937) who described the type host in 1897.

Remarks. There is a single eimerian with spheroidal oocysts from skinks, Eimeria sami Bovee, 1971, from the Ousima skink, Plestiodon marginatus Hallowell, 1861, from Japan (Bovee 1971). Oocysts of E. sami are $18(15-20) \mu \mathrm{m}$ wide with ellipsoidal SP measuring $9 \times$ $7.5 \mu \mathrm{m}$ with a $\mathrm{L} / \mathrm{W}$ ratio of 1.2 . However, our new species differs from E. sami by having 1-2 polar granule(s), which are not present in $E$. sami, as well as by having a considerably larger SP L/W ratio (1.5).

\section{Eimeria niuginiensis sp. $\mathrm{n}$.}

Figs. 7, 8, 12

Description of sporulated oocyst: Oocyst with 4 sporocysts; oocyst shape oblong and tapered at one end; colourless, bilayered wall, $\sim 1.0$ thick, smooth, outer and inner layers of equal thickness; $\mathrm{L} \times \mathrm{W}: 20.0 \times 13.1$ (18-22 $\times 12-14) ; \mathrm{L} / \mathrm{W}: 1.5$ (1.3-1.7); M, OR, PG: all absent.

Description of sporocyst and sporozoites: SP ovoidal; smooth, colourless, unilayered wall $\sim 0.3$ thick; $\mathrm{L} \times \mathrm{W}$ : $12.4 \times 5.8(12-13 \times 5-6) ; \mathrm{L} / \mathrm{W}: 2.1$ (1.9-2.5); SB, SSB: both present; PSB: absent; SR: present as scattered granules among SZ; SZ: sausage-shaped, 2.3 wide (2.2-2.4) with spheroidal ARB 1.3 (1.1-1.6) and spheroidal PRB, $3.2 \times 2.1(3.0-3.2 \times 2.0-2.2)$; single $\mathrm{N}$ slightly posterior to midpoint of body.

Ty p e host: Papuascincus stanleyanus (Boulenger) (Sauria: Scincidae). Collected 8 September 1991.

Type locality: Kaironk Village, 10 km NW Simbai, Ma-

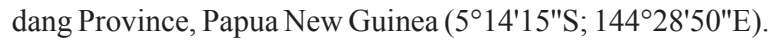

Other host species: None.

Preval e n c e: In one of $12(8 \%)$ of the type host.

Site of infection: Unknown, oocysts recovered from faeces.
Materials dep os ited: Symbiotype host in the TNHC as No. 51776. Photosyntype of sporulated oocyst deposited in the USNPC as No. 106460.

Etymology: The specific epithet is given for the country where hosts were collected, the Independent State of Papua New Guinea, utilising the pidgin spelling Niugini.

Remarks. No eimerians were previously described from members of the family Scincidae (Modrý and Jirků 2006; Abdel-Baki et al. 2008, 2013, McAllister et al. 2013b,c,d, 2014) that have oocysts in any way similar to the distinctly shaped oblong and tapered oocysts of E. niuginiensis.

\section{DISCUSSION}

As we noted above, some tetrasporocystic eimeriidlike coccidians now have been separated from the genus Eimeria. For example, Paperna and Landsberg (1989) proposed Choleoeimeria as a new genus for the eimeriid-like coccidia with endogenous stages infecting the gall bladder epithelium of reptiles; they further characterised their new genus by long ellipsoidal oocysts (L/W ratio $>1.6$ ), sporocysts without a $\mathrm{SB}$, and sporulation that begins in the lumen of the gallbladder.

A phylogenetic analysis (SSU rDNA) by Jirků et al. (2002) gave some evidence to support the separate status of Choleoeimeria as a sister clade to Eimeria within the Eimeriidae. More recent morphological and molecular studies now lend increasing support for this concept (Modrý and Jirků 2006, Sloboda and Modrý 2006, McAllister 2012a,b). Therefore, the question can be asked, why did we not include E. burseyi and, perhaps, E. goldbergi in the genus Choleoeimeria since both have sporocysts with characteristic sutures and lacking a SB? The most parsimonious reason at this time is that we have no definitive, empirical proof that our oocysts were shed completely 
sporulated, or that the endogenous stages that produced these oocysts were located in the gall bladder epithelium, because tissues were neither examined in the field nor fixed and collected for later examination. Finally, we did not sequence oocysts and have no other line of evidence to separate these oocysts from those of Eimeria. Thus, we choose to be conservative herein and although E. burseyi and E. goldbergi sporocysts possess sutures in their sporocyst walls, which could place them within Choleoeimeria, we do not have the necessary data to help us support our distinction to place them there.

Modrý and Jirků (2006) provided a summary and revision of Eimeria-like coccidia of the family Scincidae that included descriptions of new species of Acroeimeria and Choleoeimeria from Marmorosphax tricolor (Bavay) from New Caledonia. Since then, we are aware of four additional Choleoeimeria species described from skinks
(Abdel-Baki et al. 2008, 2013, Alyousif and Al-Shawa 2010, Al-Quraishy 2011). We provide descriptions of the first coccidians ever reported from skinks of the genus Papuascincus and the sixth (McAllister et al. 2013a-d, 2014) report of reptilian coccidia from PNG.

Acknowledgements. We thank the late Dr. Steve J. Upton (Kansas State University, Manhattan, KS) for technical assistance and Dr. Scott L. Gardner (Manter Parasite Collection, Lincoln, Nebraska) for parasitological training of RNF. Further appreciation is extended to Patricia A. Pilitt (USNPC) for expert curatorial assistance. The Department of Environment of PNG supplied export permits for the lizard and parasite collections. This research was funded, in part, by National Science Foundation Grants DEB 1146033 to CCA. The use of trade, product or firm names in this publication does not imply endorsement by the U.S. Government.

\section{REFERENCES}

Abdel-Baki A.S., Al-Quraishy S., Abdel-Haleem H.M. 2013: A new species of Choleoeimeria (Apicomplexa: Eimeriidae) from the lizard, Scincus hemprichii (Sauria: Scincidae). Folia Parasitol. 60: 232-236.

Abdel-Baki A.S., El-Fayomi H.M., Sakran Th., Abdel-HalEEM H.M. 2008: Choleoeimeria saqanqouri sp. nov. (Apicomplexa: Eimeriidae) infecting the gallbladder of Scincus scincus scincus (Reptilia: Scincidae) from Egypt. Acta Protozool. 47: 143-147.

Allison A. 1982: Distribution and ecology of New Guinea lizards. In: J.L. Gressitt (Ed.), Monographiae Biologicae, Volume 42. Dr. W. Junk Publishers, The Hague, pp. 803-813.

Allison A. 1996: Zoogeography of amphibians and reptiles of New Guinea and the Pacific region. In: A. Keast and S.E. Miller (Eds.), The Origin and Evolution of Pacific Island Biotas, New Guinea to Eastern Polynesia: Patterns and Processes. SPB Academic, Amsterdam, pp. 407-436.

Allison A., Greer A.E. 1986: Egg shells with pustulate surface structures: basis for a new genus of New Guinea skinks (Lacertilia: Scincidae). J. Herpetol. 20: 116-123.

Al-Quraishy S. 2011: A new Choleoeimeria species (Apicomplexa: Eimeriidae) infecting the gallbladder of Scincus mitranus (Reptilia: Scincidae) in Saudi Arabia. J. Parasitol. 97: $1125-1128$.

Alyousif M.S., Al-Shawa Y. 2010: Choleoeimeria riyadhae sp. n. (Apicomplexa: Eimeriidae) from the lizard, Scincus scincus (Sauria: Scincidae) in Saudi Arabia. J. Egypt. Soc. Parasitol. 40: $159-164$

Austin C.C., Perkins S.L. 2006: Parasites in a biodiversity hotspot: a survey of Hematozoa and a molecular phylogenetic analysis of Plasmodium in New Guinea skinks. J. Parasitol. 92: 770-777.

Bovee E.C. 1971: New species of Eimeria from lizards from Japan. Trans. Am. Microsc. Soc. 90: 336-343.

Bursey C.R., Goldberg S.R., Kraus F. 2008: Saurokoilophilia kinsellai n. gen., n. sp. (Trematoda: Hemiuridae) in the lizard Papuascincus stanleyanus (Sauria: Scincidae) from Papua New Guinea. Comp. Parasitol. 75: 24-27.
Bursey C.R., Goldberg S.R., Kraus F. 2010: Metazoan endoparasites of 14 species of skinks (Squamata: Scincidae) from Papua New Guinea. J. Nat. Hist. 44: 447-467.

CAnNon L.R.G. 1967: New coccidia from Australian lizards. II. Eimeria. Parasitology 57: 237-250.

CARINI A. 1938: Eimeria maboia n. sp. parasita do intestino do Mabuja maboia. Arq. Biol., São Paulo 22: 10.

Greer A.E. 1979: A phylogenetic subdivision of Australian skinks. Rec. Austr. Mus. 32: 339-371.

Jirkủ M., Modrý D., Šlapeta J.R., Koudela B., Lukeš J. 2002: The phylogeny of Goussia and Choleoeimeria (Apicomplexa: Eimeriorina) and the evolution of excystation structures in coccidia. Parasitol. 135: 379-390.

McAllister C.T. 2012a: A new species of Choleoeimeria (Apicomplexa: Eimeriidae) from Meller's chameleon, Trioceros melleri (Sauria: Chamaeleonidae). J. Parasitol. 98: 1001-1002.

McAllister C.T. 2012b: A new species of Choleoeimeria (Apicomplexa: Eimeriidae) from Oustalet's chameleon, Furcifer oustaleti (Sauria: Chamaeleonidae). Folia Parasitol. 59: 12-14.

McAllister C.T., Duszynski D.W., Austin C.C., Fisher R.N. 2013c: Three new species of coccidia (Apicomplexa: Eimeriidae) from skinks, Lipinia spp. (Sauria: Scincidae), from Oceania. J. Parasitol. 99: 1086-1088.

McAllister C.T., Duszynski D.W., Fisher R.N. 2013a: Two new species of Isospora (Apicomplexa: Eimeriidae) from skinks, Emoia spp. (Sauria: Scincidae), from Fiji and Papua New Guinea. J. Parasitol. 99: 677-679.

McAllister C.T., Duszynski D.W., Fisher R.N., Austin C.C. 2013b: A new species of Eimeria Schneider, 1875 (Apicomplexa: Eimeriidae) from Carlia spp. (Sauria: Scincidae) from Papua New Guinea. Syst. Parasitol. 86: 53-57.

McAllister C.T., Duszynski D.W., Fisher R.N., Austin C.C. 2014. A new species of Eimeria Schneider, 1875 (Apicomplexa: Eimeriidae) from the Solomon ground skink, Sphenomorphus solomonis (Boulenger) (Sauria: Scincidae) from Papua New Guinea. Syst. Parasitol. 87: 83-86.

McAllister C.T., Seville R.S., Duszynski D.W., Bush S.E., Fisher R.N., Austin C.C. 2013d. Two new species of Eimeria (Apicomplexa: Eimeriidae) from emerald tree skinks, Lamp- 
rolepis smaragdina (Sauria: Scincidae) from Papua New Guinea and the Philippines. Syst. Parasitol. 86: 165-171.

ModrÝ D., JIRKŮ M. 2006: Three new species of coccidia (Apicomplexa: Eimeriorina) from the marble-throated skink, Marmorosphax tricolor Bavay, 1869 (Reptilia: Scincidae), endemic to New Caledonia with a taxonomic revision of Eimeria spp. from scincid hosts. Parasitol. Res. 99: 416-428.

Paperna I., Landsberg J.H. 1989: Description and taxonomic discussion of eimerian coccidia from African and Levantine geckoes. S. Afr. J. Zool. 24: 245-355.

Sloboda M., Modrý D. 2006. New species of Choleoeimeria (Apicomplexa: Eimeriidae) from the veiled chameleon,

Received 19 August 2013
Chamaeleo calyptratus (Sauria: Chamaeleonidae), with taxonomic revision of eimerian coccidia from chameleons. Folia Parasitol. 53: 91-97.

Uetz P., Hošex J. (eds). 2013: The Reptile Database. World Wide Web electronic publication, www.reptile-database.org, 11/2013. Wilber P.G., Duszynski D.W., Upton S.J., Seville R.S., CorLISS J.O. 1998: A revision of the taxonomy and nomenclature of the Eimeria spp. (Apicomplexa: Eimeriidae) from rodents in the tribe Marmotini (Sciuridae). Syst. Parasitol. 39: 113-135.

Zweifel R.G. 1980: Results of the Archbold Expeditions. No. 103. Frogs and lizards from the Huon Peninsula, Papua New Guinea. Bull. Am. Mus. Nat. Hist. 165: 387-434. 